\title{
A Rare Case Report in Maxillary Sinus with Weber-Ferguson Approach
}

Marcelo Domingues Pinto*, Felipe Lage da Rocha, Viviane Bento Cupello, Gustavo Gaffrée Braz, Roberto Gomes Santos and Fábio Ramôa Pires

Faculty of Oral Pathology, Department of Diagnosis and Surgery, State University of Rio de Janeiro School of Dentistry, Rio de Janeiro, Brazil

\begin{abstract}
Gorlin cyst or calcifying odontogenic cyst was first reported by Gorlin. It is a very rare lesion, affecting only $0.3 \%$ of diagnosed lesions of the jaws and less than $1 \%$ of all odontogenic cysts. Its pathogenesis remains unknown until the present day, although the hypothesis that develops from remnants of the odontogenic epithelium of the jaws is accepted.

This article aims to make a brief review of the literature and report a clinical case of $\mathrm{COC}$ in the region of maxilla attended at the service of surgery and buccomaxillofacial traumatology of the Hospital Municipal Lourenço Jorge, Rio de Janeiro. The treatment of choice in this case was enucleation and peripheral osteotomy; Weber-Ferguson approach was performed for this, given the location and extension of the lesion.
\end{abstract}

Keywords: Dyspnea; Odontogenic epithelium; Oral and maxillofacial

\section{Introduction}

Calcifying odontogenic cyst (COC) was first described by Gorlin et al. In 1962, as a differentiated pathological entity, [1]. The main histopathological findings for COC are a cavity covered by odontogenic epithelium, with a pattern of keratinization and phantom cells occupying a lumen of the cyst and a variable amount of dystrophic calcification of these cells $[1,2]$. The calcification focus occurs from scattered vesicles in the bundles of phantom cells [3]. Dyspnea dysplasia and phantom cells can be observed without the fibrous capsule interior near the odontogenic epithelium, occupying a periphery of the lesion $[2,4,5]$.

This is a new generation, presenting no predilection for sex or location such as mandible or maxilla in the anterior region $[1,2,6,7]$. It is predominantly intra-osseous, but in $13 \%$ to $30 \%$ of cases it can occur in the periphery $[4,6,7]$.

Radiographically, COCs may present as delimited unilocular or multilocular radiolucent areas with radiopaque areas of varying density and size inside $[1,2,8]$. The presence of impacted teeth and root resorption are also found. $[1,5,8]$.

The COC presents a great variety in its clinical and histopathological findings presenting as cystic, solid or cystic lesions with intramural growth [9]. The world health organization recognized, as of 1992, the COC, with all its variants, as a birth of an electronic structure [10].

This fact modifies the biological behavior of the lesion, that is, a growth rate and its potential for invasion of neighboring tissues. What is the case of a solution of presence, or a degeneration of coating epithelium, in lesions of more aggressive biological behavior. This article aims to make a brief review of the literature and report a clinical case of COC attended by Oral and Maxillofacial Surgery Department of the Hospital Municipale Lourenço Jorge in Brazil.

Odontogenic Calcifying (COC) is a new institution, as a distinct entity in 1962, initially according to the World Health Organization (WHO) was classified as calcifying odontogenic tumor, today is named as a cystic entity of odontogenic cyst calcifying agent is not based on its clinical-pathological behavior $[11,12]$.

It is a rare lesion representing less than $0.3 \%$ of lesions diagnosed and less than $1 \%$ of all odontogenic cysts and tumors [13]. A wide variety of clinical and histopathological features have been published that have generated multiple classifications [13-15]. Due to this histological complexity and morphological diversity, it is widely discussed whether this lesion is a cyst or a neoplasm $[15,16]$.
The histological characteristics of the lesion are: fibrous cystic layer and a line of odontogenic epithelium, with different thicknesses formed by basal cells of the columnar or cuboidal type with cell aggregates resembling ameloblasts. Below this, there is a tissue resembling the starry reticulum of the enamel organ. A striking feature of the lesion is the presence of long, circular, non-nucleus and slightly eusinophilic cells called phantom cells [17].

A key feature for the identification of cyst and the focal object of ghost cells, may have calcifications and a presence of dysplastic dentin that may be located near the basal layer of the epithelium. In some instances, the cyst is associated with a more extensive area of dental hard tissue formation that resembles the extent of a composite or complex odontoma [18].

It is believed that COC is an injury derived from the dental odontogenic epithelium reminiscent of the dental blade, in the maxilla or mandible. It is part of the group of lesions that have phantom cells of the jaws, together with the dentinogenic tumor of phantom cells and Odontogenic Carcinoma of Phantom Cells. This lesion of central occurrence, that is, intraosseous, may present peripheral variants, in the region of gingiva and alveolar mucosa. Clinically, its presentation is an increase in volume, asymptomatic, and the age group for diagnosis is in the third decade of life, and it is not uncommon to associate odontomas mainly in the 2nd decade of life, in these cases the anterior region of the maxilla is the most affected. Regarding gender there is no predilection (9), affecting both maxilla and mandible, but the canine region is the most affected when compared to other regions, $65 \%$ of cases. Bone expansion may or may not cause painful symptomatology and is another clinically significant finding [18].

*Corresponding author: Marcelo Domingues Pinto, Faculty of Oral Pathology, Department of Diagnosis and Surgery, State University of Rio de Janeiro School of Dentistry, Rio de Janeiro, Brazil, Tel: +55 21 3111-4603, E-mail: marcelodomingues1991@hotmail.com

Received: January 02, 2018; Accepted: January 25, 2018; Published: January 30, 2018

Citation: Pinto MD, Da Rocha FL, Cupello VB, Braz GG, Santos RG, et al. (2018) A Rare Case Report in Maxillary Sinus with Weber-Ferguson Approach. Oral health case Rep 4: 141. doi:10.4172/2471-8726.1000141

Copyright: $\odot 2018$ Pinto MD, et al. This is an open-access article distributed under the terms of the Creative Commons Attribution License, which permits unrestricted use, distribution, and reproduction in any medium, provided the original author and source are credited. 
Citation: Pinto MD, Da Rocha FL, Cupello VB, Braz GG, Santos RG, et al. (2018) A Rare Case Report in Maxillary Sinus with Weber-Ferguson Approach. Oral health case Rep 4: 141. doi:10.4172/2471-8726.1000141

Page 2 of 3

Radiographically, the intraosseous cyst is an essentially destructive lesion, producing a unilocular or multilocular radiolucent image that may contain irregular radiopaque areas with the appearance of "snowflakes" $[18,19]$, and occasionally these lesions are associated with non-erupted $[20,21]$. Bone cortical plaques are often thin and expanded and may be perforated by the lesion, which usually causes tooth dislocation (18) and reabsorption of the adjacent tooth.

There is a consensus among the authors regarding the treatment recommended for COC, which would be surgical enucleation, presenting a very low relapse rate, being rare. However, if COC is associated with pathology, treatment should take into account the presence of the associated lesion [22].

\section{Case Report}

This paper reports the case of a 77-year-old JEC male patient, feoderma, who attended the outpatient clinic of the Bucomaxillofacial Surgery and Traumatology of the Municipal Hospital Lourenço Jorge in Barra da Tijuca, Rio de Janeiro, capital, reporting as main complaint a volume increase in right genic region and hard palate, daughter states that even having noticed such an alteration at two years, never sought treatment due to the absence of symptomatology.

After anamnesis, there was no evidence of any systemic alteration. Soon after, the blood pressure test and the extra and intra-oral tests were performed.

The extra-oral clinical examination revealed an increase in volume in the right genital region with nasogenic sulcus eradication without the presence of nodules sensitive to palpation (Figures 1A-1D).

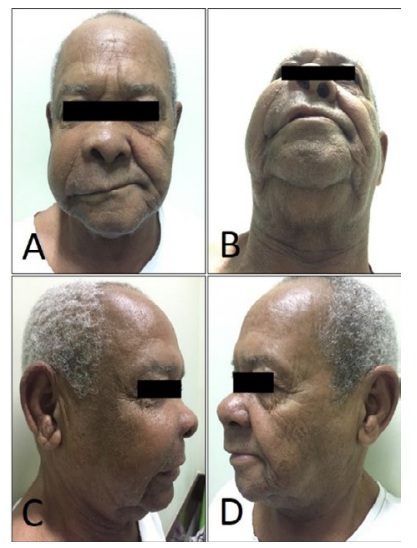

Figure 1: Pre-operative evaluation, A-Front view, B-Caudal view, C-Right profile view, D-Left profile view.

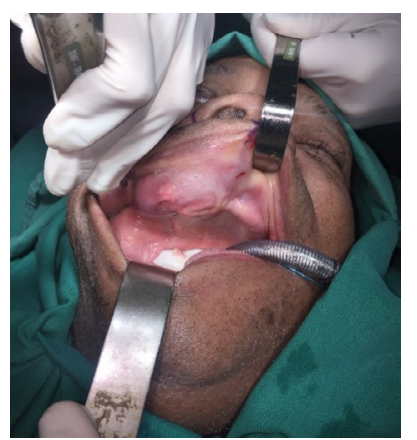

Figure 2: Intraoral lesion before surgical procedure

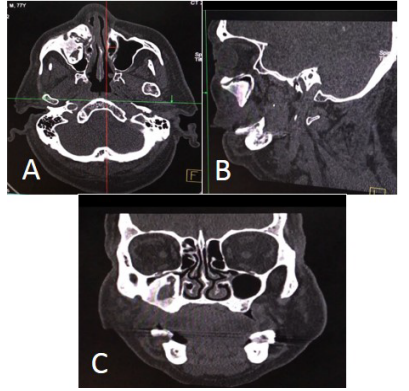

Figure 3: Imaging examination of face computed tomography, A-Axial cut, B-Sagittal cut, C-Coronal section.

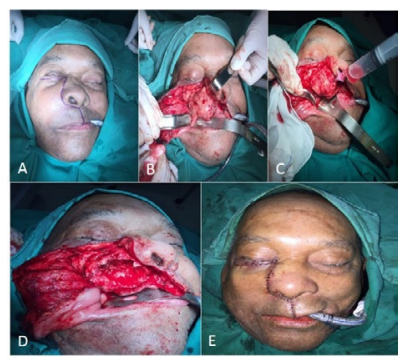

Figure 4: Surgical act of enucleation of the lesion, A-Demarcation of the incision at Weber-Ferguson access, B-Surgical exposure of the lesion, C-Aspiration puncture, evidencing net intra-lesional content, D-Enucleation and peripheral osteotomy, F-Tissue synthesis.

The intraoral examination presented a large volume increase in the hard palate region, alveolar region and right vestibule fundus, which had a rounded shape, with a firm consistency of about $8 \mathrm{~cm}$ in its largest diameter and painless (Figure 2).

Imaging examination of the type: computed tomography of the face was requested. Hyperdense topography homogeneous well delimited, invaginated to the interior of the right maxillary sinus, providing bulging of the anterior cortical bone with the limits located between the floor of the orbit and palatine bone and medially the nasal fossa causing compression of lower turbinate (Figures 3A-3C).

The diagnostic hypothesis, based on the clinical and tomographic findings, were dentinogenic tumor of phantom cells, odontogenic epithelial calcifying tumor and calcifying dystonic cyst.

With a previous histological diagnosis, the treatment plan was formulated that consisted of enucleation of the lesion.

The patient was referred to the surgical center of the Municipal Hospital Lourenço Jorge Rio de Janeiro / RJ, submitted to a surgical procedure under general anesthesia, with orotracheal intubation. Access was chosen from Weber-Ferguson to the right side, in order to better expose the lesion, as well as decrease soft tissue traction, thus helping to reduce surgical time and tissue repair. The lesion measures eight centimeters with bony bulging. Thus, dissection by planes, was performed intralesional puncture with presence of citric liquid in its interior, after the total resection of the lesion, a peripheral osteotomy was performed aiming the non-recurrence of the lesion (Figures 4A-4E).

All the material collected in the surgery was sent to the Pathology Center of the State University of Rio de Janeiro (UERJ), for histopathological analysis, the evolutionary patient without operative transplantation without intercurrences (Figures 5A and 5B). 
Citation: Pinto MD, Da Rocha FL, Cupello VB, Braz GG, Santos RG, et al. (2018) A Rare Case Report in Maxillary Sinus with Weber-Ferguson Approach. Oral health case Rep 4: 141. doi:10.4172/2471-8726.1000141

Page 3 of 3

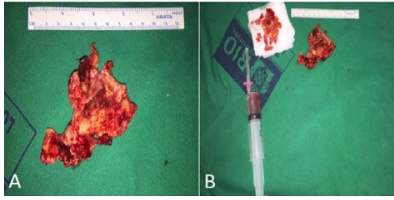

Figure 5: Surgical specimen measuring 8 centimeters in diameter, A-Syringe with liquid content, bone tissue in gauze and pathological soft tissue enucleated, B-Macroscopically, it was composed of hard tissue and soft tissue, of irregular shape and surface, brownish heart, stony and fibroelastic consistency, measuring $70 \times 50 \times 20 \mathrm{~cm}$, and preserved in $10 \%$ formalin solution.

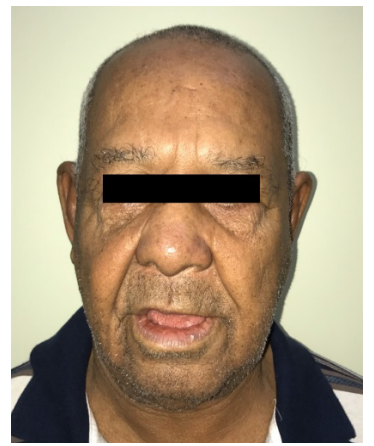

Figure 6: Patient after one year post-operatively

Histopathological examination showed fragments of cystic lesion coated with odontogenic epithelium, whose cells of the basal layer are cubic and columnar with polarized nuclei, and as suprabasal cells are strong eosinophilic without evidence of nuclei, conferring the characteristic appearance of phantom cells. These cells had areas of calcification. The cystic capsule is formed by fibrous connective tissue. Thus, there was confirmation of the diagnosis of calcifying cystic odontogenic tumor.

Patient is under postoperative control for about 1 year without the lesion reaction or other associated complaints and the aesthetic result of the incision for satisfaction (Figure 6).

\section{Conclusion}

According to a literature, the calcifying odontogenic cyst or Gorlin cyst is a cystic pathological disease with very rare neoplastic behavior and is currently classified as an odontogenic cyst of the jaws, originating from the proliferation of epithelial remnants of the dental blade of the Inner jaw or gum, often associated with even tooth [18]. In this way, the countries should be requested for the previous diagnosis, seeking, from anamnesis and complementary examinations, a more precise diagnosis, allowing the appropriate treatment.

\section{References}

1. Gorlin RJ, Pindborg JJ, Clausen FP, Vickers RA (1962) The calcifying odontogenic cyst: A possible analogue of cutaneous epithelioma of malherbe:an analysis of fifteen cases. Oral Surg Oral Med Oral Pathol 15: 1235-1243.
2. Buchner A (1991) The central (intraosseous) calcifying odontogenic cyst: An analysis of 215 Cases. J Oral Maxill Surg 49: 330-339.

3. Satomura K (1999) Initiation of ectopic epithelial calcification in a calcifying odontogenic cyst. J Oral Pathol Med 28: 330-335.

4. Rushton VE, Horner K (1997) calcifying odontogenic cyst - A characteristic CT finding. Br J Oral Maxillofac Surg 35: 196-198.

5. Yoshiura K, Tabata O, Miwa K, Tanaka T, Shimizu M, et al. (1998) computed tomographic features of calcifying odontogenic cysts. Dentomaxillofac Radio 27: 12-16.

6. Hong SP, Ellis GL, Hartman KS (1991) Calcifying odontogenic cyst: A review of ninety-two cases with reevaluation of their nature as cyst or neoplasm, the nature of ghost cells, and subclassification. Oral Surg Oral Med Oral Pathol 72: $55-64$

7. Johnson A, Fletcher M, Gold L, Chen SY (1997) Calcifying cyst: A clinicopathologic study of 57 cases with immunohistochemical evaluation cytokeratin. J Oral Maxillofac Surg 55: 679-683.

8. Neville BW (1998) Patologia oral and maxilofacial. Rio de Janeiro: Guanabara Koogan; 705.

9. Toida M (1998) So-called calcifying odontogenic cyst: review and discussion on the termonology and Classification. J oral Pathol Med 27: 49-52.

10. Kramer IRH, Pindborg JJ, Shear M (1992) Histological typing of odontogenic tumours. (2nd edn), World Health Organization, Geneva.

11. Yoon JH (2004) Hybrid odontogenic tumor of calcifying odontogenic cyst and ameloblastic fibroma. Oral Surg Oral Med Oral Pathol Oral Radio Endod 98 80-84.

12. Daniels JSM (2004) Recurrent calcifying odontogenic cyst involving the maxillary sinus. Oral Surg Oral Med oral Pathol Oral Radiol Endod 98: 660-664.

13. Alvarez SG (2005) Quiste odontogénico calcificante asociado con odontoma complejo: Presentácion de um caso y revision bibliográfica. Med Oral Patol Oral Cir Bucal 10: 243-247.

14. Praetorius $F$ (1981) Calcifying odontogenic cyst. Range, variations and neoplastic potential. Acta Odontol Scand 39: 227-240.

15. Ide F, Obara K, Mishima K, Saito I (2005) Ameloblastoma ex calcifying odontogenic cyst (Dentinogenic ghost cell tumor). J Oral Med 34: 511-512.

16. LIN CC, Chen CH, Lin LM, Chen YK, Wright JM, et al. (2004) Calcifying odontogenic cyst with ameloblastic fibroma: Report of three cases. Oral Surg Oral Med Oral Pathol Oral Radiol Endod 98: 451-460.

17. Fregnani ER, Pires FR, Quezada RD, Shih leM, Vargas PA, et al. (2003) Calcifying odontogenic cyst: clinicopathological features and immunohistochemical profile of 10 cases. J oral Pathol Med 32: 163- 170.

18. Moleri AB, Moreira LC, Carvalh JJ (2002) Comparative morphology of 7 new cases of calcifying odontogenic cyst. J Oral Maxillofac Surg 60: 689-696.

19. Soares RC (2004) Expressão imuno-histoquimica de proteinas da matriz extracelular em cistos odontogênicos calcificantes. J Bras Patol Med Lab 40: 343-349.

20. Orsini G (2002) Peripheral calcitying odontogenic cyst. J Clin Periodontol 29 83-86.

21. Hirshberg A, Buchner A (1994) Calcifying odontogenic cyst associated with odontoma. J Oral Maxi Surg 52: 555-558.

22. Durso BC, Ribeiro DA, Ferreira FBA (2004) Cisto odontogênico calcificante: uma revisão de literature. 